\title{
Self-perceived oral health among the elderly: a household-based study
}

Carla Manuela Rodrigues Nogueira' Lucilia Maria Nunes Falcão²

Sharmênia de Araújo Soares Nuto ${ }^{3}$

Maria Vieira de Lima Saintrain ${ }^{4}$

Anya Pimentel Gomes Fernandes Vieira-Meyer ${ }^{5}$

\section{Abstract}

Objective: to evaluate the self-perceived oral health status of elderly persons and its relation to self-care practices, the use of public oral health services, denture use, dental complaints and impact on everyday activities. Method: The 95 subjects of this quantitative, analytical and cross-sectional study were from Fortaleza, a state capital in the northeast of Brazil. They were aged 60 years or over and were mentally capacitated according to the Mini-Mental State Examination. The study parameters included gender, age group, race/ethnic background, level of schooling, household income, self-care practices, use and need for dentures, dental complaints, impact on everyday activities, access to oral health services, and access to information. The outcome parameter was self-perceived oral health. To verify the association between the study parameters and the outcome parameter, prevalence ratios were calculated and submitted to the Chi-squared test, the Fisher's exact test, the Mann-Whitney test and multivariate regression analysis. Result: self-perceived oral health was described as good/excellent significantly more often by women than by men $(p=0.044)$. Oral health had a negative impact on everyday activities among nearly one third of the sample ( $\mathrm{n}=29 ; 30.5 \%$ ). The mean and median values of dental complaints and impact on everyday activities were significantly lower for subjects reporting good/excellent oral health than for subjects reporting poor/fair oral health. Conclusion: it is expected that these results will strengthen oral health care for elderly persons, in order to maintain their quality of life during this stage of life.

\footnotetext{
Secretaria Municipal de Saúde, Unidade de Atenção Primária à Saúde Luis Recamonde Capelo, Fortaleza, CE, Brasil.

2 Universidade de Fortaleza (UNIFOR), Curso de Enfermagem. Fortaleza, CE, Brasil.

3 Fundação Oswaldo Cruz (FIOCRUZ) e Universidade de Fortaleza (UNIFOR), Curso de Odontologia. Fortaleza, CE, Brasil.

4 Universidade de Fortaleza (UNIFOR), Programa de pós-graduação em Saúde Coletiva. Fortaleza, CE, Brasil.

5 Fundação Oswaldo Cruz (FIOCRUZ) e Centro Universitário Christus (UNICHRISTUS), Curso de Odontologia. Fortaleza, CE, Brasil.
}

Correspondence

Sharmênia de Araújo Soares Nuto.

E-mail: shanuto@gmail.com
Keywords: Self-perception. Oral Health. Elderly. 


\section{INTRODUCTION}

An epidemiological study has reported that poor oral health conditions affect 3.9 billion people worldwide. Due to a lack of prevention and dental treatment, tooth loss was found to be the most prevalent sequela among the population ${ }^{1}$. Most dental losses are due to tooth decay, which, when left untreated, is the most common chronic disease and a major global public health problem, with significant impacts on people, health systems and economies ${ }^{2}$.

In addition to dental caries, severe periodontitis also results in tooth loss, especially among the elderly. It is the sixth most frequent of all the conditions studied, and consequently has a major impact on the well-being of people and societies in different phases of life ${ }^{1}$.

The Pesquisa Nacional de Saúde Bucal (the National Oral Health Survey) (Projeto SB BRASIL) found that an average of 27.53 decayed or missing teeth were identified among the 65 to 74 year age group, in which the component "missing" was responsible for $92 \%$ of the indices of this age group. In this same study and age group it was found that only $46.1 \%$ of the Brazilian population and $55.3 \%$ of the population of the northeast of the country do not use dentures, while $92.7 \%$ of people in Brazil and $96.1 \%$ in the northeast region require their use $e^{3}$.

However, the access of the elderly population to timely and integral dental care offered by the state is often frustrated by insufficient coverage, meaning they do not have universal access to services, guaranteed treatments or effective oral health care ${ }^{4}$. The difficulty of access to oral services is influenced by geographic, physical and operational elements, the insufficient supply aimed at the elderly, and by socioeconomic and cultural conditions. While strengthening the capacity of the Family Health Program is one possible strategy for Brazil, focus and additional efforts are required ${ }^{5}$ to achieve universality and equity of care and attention in oral health.

In the elderly phase, people turn their attention to medical services and do not seek dental services.
However, it is at this stage that oral problems are exacerbated, considering the cumulative nature of the sequelae of oral diseases ${ }^{3}$. This behavior, especially among those who no longer have teeth or only use total dentures, may suggest a lack of perception of the need for oral care. However, the understanding of an elderly person's perception of their oral health and its influence on the use of dental services, oral self-care and impact on activities of daily life, especially in the poorest regions of the country and among those dependent on the Sistema Único de Saúde (the Unified Health System) (SUS), remains limited.

Unfortunately, while for many elderly people total or partial toothlessness has no impact on perceived quality of life $^{6}$, the relationship between the absence of dentition (total or partial) and the use of dental services is unclear. Despite this, the increase in life expectancy in recent decades has resulted in a growing interest in the effect of oral health on overall health outcomes, especially those related to functionality and well-being?

In this context, the present study aims to identify the scale and negative impact of poor oral health among the elderly, information which is considered essential for the provision of adequate health care. Similarly, the study can provide support so that health education can fulfill important roles in oral and general health as well as in communication, diet and nutrition, providing the elderly with a healthy aging process.

Therefore, the objective of the present study was to investigate the self-perception of elderly persons regarding their oral health, and its relationship with measures of self-care, the use of dentures and dental services, as well as dental complaints and impact on daily life.

\section{METHOD}

A cross-sectional, analytical study with a quantitative approach was performed. The research was conducted through home visits carried out in the area covered by the Centro de Saúde da Família Fernando Diógenes (the Fernando Diógenes Family Health Center) (CSFFD), located in the city of Fortaleza in the state of Ceará. 
According to IBGE data ${ }^{8}$, the city of Fortaleza has a territorial area of $314,927 \mathrm{Km}^{2}$ and a population of 2,452,185 inhabitants, with a resident population of 237,076 people aged 60 years or more $(10.55 \%)$.

The CSFFD is located in the Granja Portugal neighborhood, which is over a hundred years old. It has a population of 39,651 inhabitants and a demographic density of approximately 71 people per $\mathrm{m}^{2}$, a mean per capita income of one minimum wage, a low social level, a lack of basic sanitation, ineffective health care and disorganized population growth which has occurred without specific guidelines, causing serious environmental impacts, such as floods associated with areas of risk ${ }^{9,10}$.

The study population consisted of elderly people aged 60 years of age or older residing in the area covered by CSFFD team 551, which has a total of ten micro-areas and a population of 6,846 inhabitants ${ }^{11}$.

For the sample calculation, a prevalence of the self-perception of oral health of very satisfied/ satisfied of $50 \%$, obtained through Project SB BRASIL $^{3}$, was considered, along with a $95 \%$ confidence level, an error of $8 \%$ and a sample universe of 401 elderly people (through a survey carried out by the health agents in the region). A need for 110 interviewees was calculated.

A random simple sample design was applied, in which all the individuals in the population studied had an equal probability of being selected. Each element of the sample universe was assigned a unique number and a random draw of the components of the sample was carried out.

To be included in the study, the participants had to be 60 years old or older when they answered the questionnaire and be residents of micro-areas that possess health agents, as the sample universe was defined by the list provided by these professionals. The following exclusion criteria were applied: mentally handicapped elderly persons, evaluated through the Mini Mental State Exam (MMSE), which identified the individuals as oriented in time and space and capable of interacting during data collection, in order to provide reliability in the responses. The cutoff point for the elderly persons with up to four years of schooling was 24 points and for illiterate individuals it was 17 points $^{12}$. Elderly persons who were not found at home after a second scheduled visit did not participate in the study.

The data was collected from February to April 2014. Two instruments were applied: the first a neuropsychological evaluation and the second a questionnaire addressing specific oral health issues, based on Projeto SB BRASIL ${ }^{3}$ and the studies of Bulgarellii ${ }^{13}$.

The questionnaires were applied verbatim to the elderly by a researcher on a home visit. Prior to this phase, a pre-test of the questionnaire was carried out with ten elderly people, in order to verify the clarity of the language, the understanding of the questions by the interviewee and the average time of application.

The independent variables included sex, age group, ethnicity, schooling, family income, selfcare practices, use and need for dentures, dental complaints, impact on daily life and access to service and information, while the dependent variable was self-perception of oral health.

The variables dental complaints and impact on everyday activities are composite variables, resulting from self-reports of the presence or not of the discomforts listed in the form. The variable dental complaints resulted from the sum of self-reports of pain, missing teeth, discoloration, speech difficulties, gingival bleeding, dry mouth, soft teeth, crooked teeth, difficulty swallowing or chewing, discomfort in dentures, bad breath and injuries. Impact on everyday activities, meanwhile, resulted from the sum of the feelings of embarrassment, nervousness, difficulty in carrying out tasks of daily living, not being able to enjoy oneself and sleeping poorly due to oral problems. In each consolidated continuous variable, the self-reports had the same weight in the final summation, and were analyzed through measures of central tendency.

Simple and relative frequencies were calculated for the characterization of the sample, as well as the prevalence ratio, and the Chi-squared, Fisher's Exact and Mann-Whitney tests were applied for the identification of measures of association between exposures and outcomes. Multivariate regression 
was performed to investigate the impact of age, number of complaints and impact on daily activities (the continuous variables of the study) on the selfperception of oral health. Statistical analysis included median (Md) and interquartile distances (Q1 and Q3). The normality of the data was verified, and as the distribution was not normal, the Mds were used to characterize the quantitative variables and the Mann-Whitney test was applied to compare them with self-perception of oral health. In all tests, the level of significance was set at $5 \%(\mathrm{p}<0.05)$.

The study design was approved by the Ethics Research Committee of the Universidade Estadual do Ceará (Ceará State University) under number $\mathrm{N}^{\circ} 364.432$ and all the ethical and legal guidelines contained in Resolution No 466/12 were respected. The nature of the study was made clear to all the interviewees in advance and only those that signed a FICF (Free and Informed Consent Form) participated in the project.

\section{RESULTS}

Of the total of 110 elderly people to be interviewed, 95 questionnaires were completed effectively, as one elderly person had changed address, two had died, four refused to participate in the survey and two were not found at home on a second scheduled visit. In addition, six mentally impaired elderly persons were excluded from the sample following evaluation by the MMSE. The studied group therefore contained 95 elderly persons, whose age varied from 60 to 91 years with a mean of $67.9( \pm 6.9)$ years.

Table 1 shows the sociodemographic characteristics of the elderly persons, the majority of whom were women $(\mathrm{n}=62 ; 65.3 \%)$, aged $60-70$ years $(\mathrm{n}=67$, $70.5 \%)$, brown-skinned (mixed race) ( $\mathrm{n}=94,98.9 \%)$, who had never studied or who had studied until the $4^{\text {th }}$ grade $(\mathrm{n}=71,74.8 \%)$ and had a family income of up to two minimum wages $(\mathrm{n}=86,90.6 \%$ ). The association between skin color/ethnicity and the outcome was not tested, as practically the entire sample consisted of people who declared themselves to be brown-skinned/mixed race. It is noteworthy that more women than men had an excellent/good self-perception of oral health $(p=0.044)($ Table 1$)$.
Table 2 describes measures of self-care, with 63 $(66.3 \%)$ elderly persons reporting performing oral cleaning once or twice a day. However, only two elderly persons $(4.5 \%)$ used dental floss and seven (7.4\%) used mouthwash. As only two elderly people used dental floss, this association was not calculated. When evaluating the relationship between the selfcare variables and the self-perception of oral health, no variables demonstrated a causal relationship.

Table 3 focuses on the distribution of the presence of teeth/fixed prostheses and the use of dentures. It is demonstrated that more than half $(n=50,52.6 \%)$ of the elderly persons were totally edentulous, two thirds $(n=63,66.3 \%)$ used upper dentures and only one third $(n=31,32.6 \%)$ used lower dentures. None of the elderly interviewed still had all their teeth.

Regarding self-perception of the need for denture replacement, more than a third $(n=36$; $37.9 \%$ ) believed that they did not need to change their dentures, and 33 (34.7\%) described a need for replacement. However, 28 of the elderly persons $(29.5 \%)$ reported that their dentures moved during chewing, 18 (18.9\%) said that their dentures injured their mouths and $14(14.7 \%)$ said that they made speaking difficult. There was a statistically significant difference between the elderly persons with natural teeth and those who did not have any teeth $(p<0.001)$. Elderly persons who did not have any teeth had a better evaluation of their oral health $(\mathrm{PR}=1.69)$. However, the self-perception of the majority $(55.6 \%)$ of those with natural teeth considered their oral health to be very good or good. Those who used upper dentures had a better self-perception of oral health than those who did not $(\mathrm{p}=0.057$ and $\mathrm{PR}=1.32)$ (Table 3$)$.

Table 4 examines self-perception of oral health versus access to dental services. It was observed that $87(91.6 \%)$ of the elderly persons had not consulted a dentist in the previous six months, but presented a higher prevalence ratio in terms of considering their oral health as excellent or good $(\mathrm{PR}=1.56)$; $91(95.8 \%)$ had no information about oral health, but presented a higher prevalence ratio in terms of considering their oral health as excellent or good ( $\mathrm{PR}=1.54)$; Likewise, 91 (95.8\%) did not visit the 
Table 1. Simple and percentage frequencies and prevalence ratio of socio-demographic data by self-perception of oral health. Fortaleza, Ceará, 2014.

\begin{tabular}{|c|c|c|c|c|c|}
\hline \multicolumn{6}{|c|}{ Self-perception } \\
\hline Variables & $\begin{array}{l}\text { Excellent/Good } \\
\mathrm{n}(\%)\end{array}$ & $\begin{array}{l}\text { Fair/Poor } \\
\text { n }(\%)\end{array}$ & Total & $\begin{array}{l}\text { Prevalence ratio } \\
\text { (CI 95\%) }\end{array}$ & $P$ value \\
\hline \multicolumn{6}{|l|}{ Sex } \\
\hline Female & $51(82.3)$ & $11(17.7)$ & $62(65.3)$ & $1.29(0.97-1.71)$ & $0.044^{*}$ \\
\hline Male & $21(63.6)$ & $12(36.4)$ & $33(34.7)$ & 1.00 & \\
\hline \multicolumn{6}{|l|}{ Age group } \\
\hline 60 to 70 & $48(71.6)$ & $19(28.4)$ & $67(70.5)$ & 1.00 & \\
\hline 71 or more & $24(85.7)$ & $4(14.3)$ & $28(29.5)$ & $1.20(0.97-1.48)$ & $0.231 *$ \\
\hline \multicolumn{6}{|l|}{ Ethnicity ${ }^{+}$} \\
\hline Black (Afro-Brazilian) & $1(100.0)$ & - & $1(1.1)$ & & \\
\hline Brown (Mixed-Race) & $71(75.5)$ & $23(24.5)$ & $94(98.9)$ & & \\
\hline \multicolumn{6}{|l|}{ Schooling (years) } \\
\hline Never studied & $21(80.8)$ & $5(19.2)$ & $26(27.4)$ & $1.1(0.85-1.42)$ & $0.776^{*}$ \\
\hline Four or fewer & $33(73.3)$ & $12(26.7)$ & $45(47.4)$ & 1.00 & \\
\hline Five or more & $18(75)$ & $6(25)$ & $24(25.3)$ & $1.02(0.76-1.37)$ & \\
\hline \multicolumn{6}{|l|}{ Family income (minimum salary) } \\
\hline Less than one MS or no income & $20(83.3)$ & $4(16.7)$ & $24(25.3)$ & $1.25(0.76-2.05)$ & $0.528 * *$ \\
\hline 1 to 2 & $46(74.2)$ & $16(25.8)$ & $62(65.3)$ & $1.11(0.69-1.81)$ & \\
\hline More than 2 & $6(66.7)$ & $3(33.3)$ & $9(9.5)$ & 1.00 & \\
\hline
\end{tabular}

* Chi-squared test; ${ }^{* *}$ Fisher's exact test; + Due to the homogeneity of the sample the prevalence ratio was not calculated.

dentist regularly, but presented a higher prevalence ratio in terms of considering their oral health as excellent or very good $(\mathrm{PR}=1.54)$.

The fact that the elderly did not regularly visit the dentist was attributed to the following main justifications: "do not feel pain, so do not need to go to the dentist" ( $n=62,65.2 \%$ ); "no longer have teeth and so no longer require dental care" ( $n=43$; $45.2 \%$ ); "cannot get access to dental care" ( $n=30$, $31.5 \%$ ); "difficulty getting to the dentist" ( $\mathrm{n}=21$; $22.1 \%$ ); "fear of the dentist" ( $n=4,4.2 \%)$; "no one to take me to the dentist" ( $n=2,2.1 \%)$. There was no relation between the use of dental services and self-perception of oral health $(\mathrm{p}>0.05)$.

One third of the elderly persons $(n=29$; $30.5 \%$ ) believed that oral health had an impact on their daily lives. Of these, one third ( $n=29 ; 30.5 \%)$ felt embarrassed when smiling or talking; 12
$(12.6 \%)$ stopped enjoying themselves; seven (7.4\%) reported nervousness or irritation; six (6.3\%) slept poorly and three $(3.2 \%)$ had difficulties performing daily tasks.

Table 5 shows the existence of a significant difference $(p<0.001)$ between the median number of situations that have an impact on daily life and the self-perception of oral health. Elderly persons who reported an excellent or good oral perception of health experienced fewer situations that impacted on their daily life than those who reported a fair or poor perception of oral health.

Of the elderly persons interviewed, 81 (85.26\%) had dental complaints. This indicator was based on the self-reported presence of pain, missing teeth, discoloration, speech difficulties, gingival bleeding, dry mouth, soft teeth, difficulty in swallowing or chewing, discomfort with dentures, bad breath and injuries. 
Table 2. Simple and percentage frequencies and prevalence ratio of measures of self-care by self-perception of oral health. Fortaleza, Ceará, 2014.

\begin{tabular}{|c|c|c|c|c|c|}
\hline \multicolumn{6}{|c|}{ Self-perception } \\
\hline Variables & $\begin{array}{l}\text { Excellent/Good } \\
\mathrm{n}(\%)\end{array}$ & $\begin{array}{l}\text { Fair/Poor } \\
\mathrm{n}(\%)\end{array}$ & Total & $\begin{array}{l}\text { Prevalence ratio } \\
(\text { CI } 95 \%)\end{array}$ & $P$ value \\
\hline \multicolumn{6}{|l|}{$\begin{array}{l}\text { How often do you clean your } \\
\text { teeth each day? }\end{array}$} \\
\hline Don't clean & $5(83.3)$ & $1(16.7)$ & $6(6.3)$ & $1.27(0.81-2.01)$ & \\
\hline Once or twice & $50(79.4)$ & $13(20.6)$ & $63(66.3)$ & $1.21(0.89-1.65)$ & $0.376^{* *}$ \\
\hline Three times or more & $17(65.4)$ & $9(34.6)$ & $26(27.4)$ & 1.00 & \\
\hline \multicolumn{6}{|c|}{ Do you use dental floss every day? ${ }^{+}$} \\
\hline Yes & $2(100)$ & - & $2(4.5)$ & & \\
\hline No & $22(52.4)$ & $20(47.6)$ & $42(95.5)$ & & \\
\hline \multicolumn{6}{|l|}{ Do you use mouthwash? } \\
\hline Yes & $5(71.4)$ & $2(28.6)$ & $7(7.4)$ & 1.00 & $0.675^{* *}$ \\
\hline No & $67(76.1)$ & $21(23.9)$ & $88(92.6)$ & $1.07(0.66-1.73)$ & \\
\hline \multicolumn{6}{|l|}{$\begin{array}{l}\text { How often do you clean } \\
\text { your dentures? }\end{array}$} \\
\hline Not every day & $2(66.7)$ & $1(33.3)$ & $3(4.2)$ & 1.00 & \\
\hline Once per day & $14(87.5)$ & $2(12.5)$ & $16(22.9)$ & $1.31(0.58-2.98)$ & $0.587 * *$ \\
\hline Twice or three times per day & $42(82.4)$ & $9(17.6)$ & $51(72.9)$ & $1.24(0.55-2.78)$ & \\
\hline \multicolumn{6}{|l|}{$\begin{array}{l}\text { What do you use to clean } \\
\text { your dentures? }\end{array}$} \\
\hline Toothbrush and toothpaste & $53(85.5)$ & $9(14.5)$ & $62(65.3)$ & $1.37(0.79-2.36)$ & $0.132 * *$ \\
\hline Others & $5(62.5)$ & $3(37.5)$ & $8(34.7)$ & 1.00 & \\
\hline
\end{tabular}

* Chi-squared test; ** Fisher's exact test; + Due to the homogeneity of the sample the prevalence ratio was not calculated.

Table 3. Simple and percentage frequencies and prevalence ratio of presence of natural teeth and use of dentures by self-perception of oral health. Fortaleza, Ceará, 2014.

\begin{tabular}{|c|c|c|c|c|c|}
\hline \multirow[b]{2}{*}{ Variables } & \multicolumn{3}{|c|}{ Self-perception } & \multirow[b]{2}{*}{$\begin{array}{l}\text { Prevalence ratio } \\
\text { (CI 95\%) }\end{array}$} & \multirow[b]{2}{*}{$P$ value } \\
\hline & $\begin{array}{l}\text { Excellent/Good } \\
\mathrm{n}(\%)\end{array}$ & $\begin{array}{l}\text { Fair/Poor } \\
\text { n }(\%)\end{array}$ & Total & & \\
\hline \multicolumn{6}{|c|}{ How many natural teeth and/or fixed prosthetic teeth do you have } \\
\hline Has natural teeth & $25(55.6)$ & $20(44.4)$ & $45(47.4)$ & 1.00 & $<0.001^{*}$ \\
\hline Has no teeth & $47(94.0)$ & $3(6.0)$ & $50(52.6)$ & $1.69(1.29-2.22)$ & \\
\hline \multicolumn{6}{|l|}{ Upper dentures } \\
\hline Use & $52(82.5)$ & $11(17.5)$ & $63(66.3)$ & $1.32(0.99-1.77)$ & 0.057 \\
\hline Don't use & $20(62.5)$ & $12(37.5)$ & $32(33.7)$ & 1.00 & \\
\hline \multicolumn{6}{|l|}{ Lower } \\
\hline Use & 27 (87.1) & $4(12.9)$ & $31(32.6)$ & $1.24(1.01-1.53)$ & 0.125 \\
\hline Don't use & $45(70.3)$ & $19(29.7)$ & $53(55.8)$ & 1.00 & \\
\hline
\end{tabular}

* Chi-squared test; ${ }^{* *}$ Fisher's exact test. 
Table 4. Simple and percentage frequencies and prevalence ratio of access to dental services by self-perception of oral health. Fortaleza, Ceará, 2014.

\begin{tabular}{|c|c|c|c|c|c|}
\hline \multirow[b]{2}{*}{ Variables } & \multicolumn{3}{|c|}{ Self-perception } & \multirow[b]{2}{*}{$\begin{array}{l}\text { Prevalence ratio } \\
\text { (CI 95\%) }\end{array}$} & \multirow[b]{2}{*}{$P$ value } \\
\hline & $\begin{array}{l}\text { Excellent/Good } \\
\mathrm{n}(\%)\end{array}$ & $\begin{array}{l}\text { Fair/Poor } \\
\mathrm{n}(\%)\end{array}$ & Total & & \\
\hline \multicolumn{6}{|c|}{ Have you been to the dentist in the last six months? } \\
\hline Yes & $4(50)$ & $4(50)$ & $8(8.4)$ & 1.00 & $0.075^{*}$ \\
\hline No & $68(78.2)$ & $19(21.8)$ & $87(91.6)$ & $1.56(0.77-3.15)$ & \\
\hline \multicolumn{6}{|c|}{ Have you had access to information about oral health? } \\
\hline Yes & $2(50)$ & $2(50)$ & $4(4.2)$ & 1.00 & $0.246^{* *}$ \\
\hline No & $70(76.9)$ & $21(23.1)$ & $91(95.8)$ & $1.54(0.57-4.13)$ & \\
\hline \multicolumn{6}{|c|}{ Do you go to the dentist regularly? } \\
\hline Yes & $2(50)$ & $2(50)$ & $4(4.2)$ & 1.00 & $0.246^{* *}$ \\
\hline No & $70(76.9)$ & $21(23.1)$ & $91(95.8)$ & $1.54(0.57-4.13)$ & \\
\hline
\end{tabular}

${ }^{*}$ Chi-squared test; **Fisher's exact test.

Table 5. Inference between dental complaints, impacts on daily live and self-perception of oral health. Fortaleza, Ceará, 2014.

\begin{tabular}{llll}
\hline & \multicolumn{2}{l}{ Self-perception de saúde bucal } & \\
Variables & Excellent/Good & Fair/Poor & P value \\
& Median $\left(1^{\circ} \mathrm{Q}-3^{\circ} \mathrm{Q}\right)$ & Median $\left(1^{\circ} \mathrm{Q}-3^{\circ} \mathrm{Q}\right)$ & $<0.001$ \\
\hline Complaints & $2(1-3)$ & $4(3-5)$ & $<0.001$ \\
\hline Impact on daily activities & $0(0-0)$ & $1(0-3)$ & \\
\hline
\end{tabular}

Mann-Whitney Test.

An association was identified between the median number of dental complaints and the self-perception of oral health $(\mathrm{p}<0.001)$. Elderly patients who reported an excellent or good perception of oral health presented a lower number of complaints (Table 5).

To try to understand the relationship between the continuous variables age, number of dental complaints and impact on daily activities and the self-perception of oral health, regression analysis was carried out, with the outcome the selfperception of oral health and the other exposure variables. The equation generated had an adjusted $r^{2}$ of $0.247(p<0.001)$, showing that $24.7 \%$ of the variation in self-perception could be explained by the equation (which had a constant of 2.389765; $\mathrm{p}<0.001$ ), specifically by the variables number of dental complaints (coefficient 0.0928273, $\mathrm{p}=0.011$ ) and impact on daily activities (coefficient 0.1709774; $\mathrm{p}=0.008$ ), although the influence of age was not significant $(p=0.399)$. As such, the greater the number of dental complaints and the more severe the impact on daily activities, the worse the self-perception of oral health.

\section{DISCUSSION}

One differential of the present study is that it was carried out based on homes in an area covered by a Family Health Strategy, unlike most studies with elderly persons, which use institutionalized populations. The study of this environment, together with the simple random sample design, allows a more precise characterization of a low income elderly population in the periphery of a large urban center. 
As with other studies ${ }^{12,14-16}$, there were greater numbers of elderly women than elderly men in the present study. This greater female presence can be explained by the fact that male mortality is higher than female mortality in younger age groups ${ }^{8}$.

Other expected realities were the low levels of schooling and income of the sample population. Low schooling is predictable in populations over 60 years of age in Brazil, as school access was historically restricted ${ }^{13}$. The low incomes of the interviewees are because the study was carried out with residents of a region with a mean per capita income of one monthly minimum wage ${ }^{10}$. Similar results were observed in a study by Xavier et al. ${ }^{17}$. A higher income can directly reflect on active aging, as it allows financial autonomy when dealing with health, social and alimentary needs.

Knowledge about the self-assessment of the health of the population is important in dentistry so that people's behavior and how they assess their needs can be understood, in order to assist them to adhere to healthy behaviors. This knowledge is even more important in relation to the elderly, considering that one of the main reasons why this group does not seek dental service is their own lack of perception of their needs ${ }^{18}$, together with social, cultural, lifestyle and economic issues ${ }^{19}$.

The self-perception and self-assessment of health is understood as the interpretation that a person makes in relation to their state of health and their experiences of daily life, based on the information and the knowledge about health and illness available, which are also influenced by previous experiences and the social, cultural and historical contexts of each individual ${ }^{18}$.

When studying the self-perceptions of oral health conditions, SB Brasil ${ }^{3}$, Martins et al. ${ }^{18}$ and Lima et al. ${ }^{20}$ identified positive self-perceptions of oral health despite high edentulism. Hailkal et al. ${ }^{14}$ found that of a group of elderly persons with an average of only 4.8 teeth present in their mouths, $60 \%$ did not perceive a need for treatment or dental care.

These findings corroborate the regression analysis of the present study, which had an outcome of self-perception of oral health and other exposure variables, with a greater number of dental complaints and a higher impact on daily activities associated with a lower self-perception of oral health. A total of $75.7 \%$ of such elderly people perceived their oral health as excellent or good, although $95.7 \%$ of those interviewed said they had few or no teeth.

In a study carried out in the south of Brazil, Gabardo et al. ${ }^{21}$ concluded that there was a greater chance of a lower self-perception of oral health among women, elderly women, those with a lower quality of life and social support scores, individuals with poor eating habits, smokers, and residents of low-income census tracts.

A study by Bulgarelli ${ }^{13}$ concluded that oral health care declined with advancing age and that the elderly described feeling satisfied with their oral health conditions. The same study reported that being completely edentulous did not necessarily mean assigning negative values to this condition. Saintrain and Souza ${ }^{22}$ found that elderly persons identified two dimensions of their oral health: one with a negative impact when describing the difficulties after the loss of their teeth and the other with a positive impact in terms of pain relief, concluding, therefore, that clinically defined needs are not always the same as subjective needs.

To explain the fact that elderly persons with poor oral health conditions perceive their oral health in a positive manner, Haikal et al. ${ }^{14}$ reported that such individuals passively accept the deterioration of their oral condition, adopting a kind of inertia about the situation, which they consider "natural". Agostinho et al. ${ }^{23}$, meanwhile, identified an association between the self-perception of oral health and the actual condition, but found that prosthetic rehabilitation did not contribute to the improvement of people's perception.

Bulgarelli ${ }^{12}$ believes that working with people about the idea of feeling good about oral health is fundamental, as in order to live satisfactorily in society, individuals must be able to chew, have an aesthetically acceptable appearance, the absence of disorders and pain, and access to good nutrition, 
and so oral health should be included in the construction of meanings about health. In another study on the elderly, Mestriner et al. ${ }^{24}$ concluded that self-perception of oral health and income affect the impact of oral health on quality of life. Rigo et al. $^{25}$ identified that elderly persons with higher levels of satisfaction with life exhibited a better self-perception of oral health.

The facts that the present study focused on a single health unit and that the sample calculation was performed for a prevalence study and not for a study of association are limitations, which prevent the results from being extrapolated to other populations. However, it is hoped that this study can be used as a base for the development of preventive, educational and care programs that value oral health, provide clarity on self-care, promote health and prevent oral diseases among the elderly, whose oral health reality is the reflection of the invasive and inaccessible dentistry practices to which they were submitted in the past.

\section{CONCLUSION}

While the predominance of edentulism and the use, need and replacement of dental prostheses demonstrate the precarious condition of the oral health of the elderly persons interviewed, they reported an excellent or good perception of their oral health.

A greater positive self-perception in oral health was associated with older women, older elderly persons, with lower levels of schooling, irregular access to dental services and with fewer dental complaints and situations that impacted their daily activities.

Population aging, the growing numbers of patients with chronic diseases, and the need for these patients to access public health services require greater efforts by the Unified Health System to train and improve its health units to ensure safe, universal access and to treat users equitably. Thus, it is hoped that the results of this study can be used as a base for the development of preventive, educational and care programs that value oral health, provide clarity on self-care, promote health and prevent oral diseases among the elderly, so that they can maintain the oral health conditions necessary to live this stage of life with quality.

\section{Annex A}

\section{QUESTIONNAIRE}

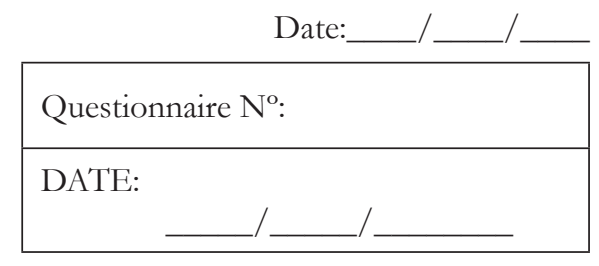

\begin{tabular}{|l|l|l|}
\hline \multicolumn{3}{|c|}{ GENERAL INFORMATION } \\
\hline 1. DATE OF BIRTH: & 2. AGE (YEARS): & $(\quad) \mathrm{M} \quad(\quad) \mathrm{F}$ \\
\hline & \\
\hline $\begin{array}{l}\text { 4. ETHNICITY: } \\
(\quad) \text { WHITE ( ) YELLOW (Asian-Brazilian) } \quad(\quad) \text { BLACK (Afro-Brazilian) } \quad(\quad) \text { INDIGENOUS } \\
(\quad) \text { BROWN (Mixed Race) }\end{array}$ \\
\hline $\begin{array}{l}\text { 5.SCHOOLING (COMPLETE YEARS): } \\
(\quad) \text { NEVER STUDIED } \quad(\quad) \leq 4 \text { YEARS } \quad(\quad) 5 \text { TO } 8 \text { YEARS } \quad(\quad) \geq 9 \text { YEARS }\end{array}$ \\
\hline
\end{tabular}


6. FAMILY INCOME:

( ) NO FAMILY INCOME

( ) FROM 1 TO LESS THAN 2 MINIMUM SALARIES

( ) LESS THAN ONE MINIMUM SALARY

( ) MORE THAN FOUR MINIMUM SALARIES

( ) BETWEEN 2 AND 3 MINIMUM SALARIES

( ) COULD NOT SAY

SELF-CARE ACTIVITIES, DENTAL COMPLAINTS AND SELF-REPORTED ORAL HEALTH

7. HOW OFTEN DO YOU CLEAN YOUR TEETH EACH DAY?

( ) ONCE ( ) TWICE （ ) THREE OR MORE

( ) DON'T CLEAN EVERY DAY ( ) NEVER

\begin{tabular}{|l|l|}
\hline 8. DO YOU USE DENTAL FLOSS? & 9. DO YOU USE MOUTHWASH? \\
$(\quad)$ YES $(\quad)$ NO ( ) DON’T USE & $(\quad)$ YES $(\quad)$ NO
\end{tabular}

10. HOW MANY NATURAL TEETH AND/OR FIXED PROSTHESES DO YOU HAVE:

( ) I HAVE NO TEETH （） I HAVE FEW TEETH

( ) I HAVE ALMOST ALL MY TEETH （ ) I HAVE ALL MY TEETH

11. ON THE USE OF DENTURES:

UPPER: ( ) HAVE AND USE （ ) HAVE AND DON'T USE （ ) HAVE AND USE SOMETIMES ( ) DON'T HAVE

TIME OF USE:

LOWER: ( ) HAVE AND USE （ ) HAVE AND DON`T USE ( ) HAVE AND USE SOMETIMES ( ) DON'T HAVE TIME OF USE:

12. WHAT COMPLAINTS DO YOU HAVE IN RELATION TO YOUR MOUTH?

( ) TOOTH PAIN WHEN CHEWING （ ) SOFT TEETH

( ) MISSING TEETH

( ) CROOKED TEETH)

( ) DISCOLORED TEETH

( ) DIFFICULTY CHEWING OR SWALLOWING

( ) DIFFICULTY SPEAKING

( ) DISCOMFORT WITH DENTURES

( ) GUM BLEEDING

( ) BAD BREATH

( ) DRY MOUTH AND/OR BITTER TASTE

( ) PRESENCE OF INJURIES

( ) OTHER COMPLAINTS

( ) NO COMPLAINTS

13. DO THE DENTURES YOU USE?

( ) HURT YOU ( ) MOVE DURING CHEWING

( ) MAKE SPEAKING DIFFICULT （）DON'T CAUSE DISCOMFORT （）DOES NOT APPLY

14. HOW FREQUENTLY DO YOU CLEAN YOUR DENTURES?
( ) ONCE A DAY
( ) TWICE A DAY
( ) THREE OR MORE TIMES A DAY
( ) NOT EVERY DAY （） DOES NOT APPLY

15. WHAT DO YOU USE TO CLEAN YOUR DENTURES?

（ ) TOOTHBRUSH AND TOOTHPASTE （） TOOTHBRUSH ONLY

( ) TOOTHRBUSH AND SOAP ( ) OTHER PRODUCTS （）DOES NOT APPLY 


\section{SELF-PERCEIVED ORAL HEALTH AND IMPACT ON DAILY LIFE}

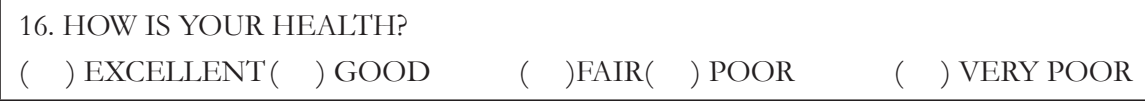

\begin{tabular}{|c|c|}
\hline $\begin{array}{l}\text { 22. HAVE YOU VISITED A DOCTOR IN THE LAST } \\
\text { SIX MONTHS? } \\
\begin{array}{ll}(\quad) \text { YES } & (\quad) \text { NO }\end{array}\end{array}$ & $\begin{array}{l}\text { 23. HAVE YOU VISITED A DENTIST IN THE LAST SIX } \\
\text { MONTHS? } \\
\left(\begin{array}{l}\text { )YES }(\quad) \text { NO } \\
\end{array}\right.\end{array}$ \\
\hline $\begin{array}{l}\text { 24. HAVE YOU HAD ACCESS TO INFORMATION } \\
\text { ABOUT ORAL HEALTH? } \\
\left(\begin{array}{l}\text { ) YES ( ) NO } \\
\end{array}\right.\end{array}$ & $\begin{array}{l}\text { 25. DO YOU VISIT THE DENTIST REGULARLY? } \\
(\quad) \mathrm{YES}(\quad) \mathrm{NO}\end{array}$ \\
\hline $\begin{array}{l}\text { 26. IF YOU DO NOT VISIT THE DENTIST REGULA } \\
\text { ( ) FEAR OF DENTIST } \\
\text { ( ) NO ONE TO TAKE ME TO THE DENTIST } \\
\text { ( ) DIFFICULTY GETTING TO DENTIST } \\
\text { ( ) CANNOT GET ACCESS TO DENTAL CARE } \\
(\quad) \text { NO LONGER HAVE TEETH AND SO NO LON } \\
(\quad) \text { DO NOT FEEL PAIN, SO DO NOT NEED TO G } \\
(\quad) \text { OTHER REASONS } \\
(\quad) \text { DOES NOT APPLY }\end{array}$ & $\begin{array}{l}\text { Y, WHAT IS THE REASON? } \\
\text { R REQUIRE DENTAL CARE } \\
\text { TO THE DENTIST }\end{array}$ \\
\hline
\end{tabular}




\section{REFERENCES}

1. World Dental Federation. The Challenge of Oral Disease- a call for global action. The Oral Health Atlas [Internet]. 2nd ed. Geneva: FDI/World Dental Federation; 2015 [acesso em 15 nov. 2016]. Disponível em: http://www.fdiworldental.org/ media/77552/complete_oh_atlas.pdf

2. World Health Organization. World report on ageing and health 2015 [Internet]. Geneva: WHO; 2015 [acesso em 5 nov. 2016]. Disponível em: http://www. who.int/kobe_centre/mediacentre/world_report_ on_ageing_and_health_eng.pdf.

3. Brasil. Ministério da Saúde, Secretaria de Atenção à Saúde, Secretaria de Vigilância em Saúde. SB Brasil 2010: Pesquisa Nacional de Saúde Bucal [Internet]. Brasília, DF: MS; 2011 [acesso em 15 nov. 2016]. Disponível em: http://dab.saude.gov.br/CNSB/ sbbrasil/arquivos/projeto_sb2010_relatorio_final. pdf

4. Mello ALSF, Erdmann AL, Caetano JC. Saúde bucal do idoso: por uma política inclusiva. Texto \& Contexto Enferm. 2008;17(4):696-704.

5. Banco mundial. Envelhecendo em um Brasil mais velho: implicações do envelhecimento populacional para o crescimento econômico, a redução da pobreza, as finanças públicas e a prestação de serviços. Banco Internacional para a Reconstrução e o Desenvolvimento 2011 [Internet]. Washington, DC: Banco Mundial; 2011 [acesso em 28 set. 2015]. Disponível em: http://siteresources. worldbank.org/BRAZILINPOREXTN/ Resources/3817166-1302102548192/Envelhecendo_ Brasil_Sumario_Executivo.pdf

6. Viana AAF, Gomes MJ, Carvalho RB, Oliveira ERA. Acessibilidade dos idosos brasileiros aos serviços odontológicos. RFO 2010;15(3):319-24.

7. Andrade FB, Lebrão ML, Santos JLF, Duarte YAO. Relationship between oral health and frailty in community-dwelling elderly individuals in Brazil. J Am Geriatric Soc. 2013;61(5):809-14.

8. Instituto Brasileiro de Geografia e Estatística. Censo demográfico 2010. Rio de Janeiro: IBGE; 2010.

9. Freitas JL, Costa FCA. Diagnóstico do bairro da Granja Portugal, no Grande Bom Jardim: "suas histórias e realidades": construindo novos olhares. Fortaleza: Visão Mundial; 2011.

10. Lemos ECL, Cavalcante IN, Sabadia JAB, Gomes MCR, Medeiros FW, Santos DM. Qualidade das águas subterrâneas e doenças de veiculação hídrica na porção sudoeste do Município de Fortaleza Ceará. Rev Geol. 2009;2(2):151-65.
11. Fortaleza. Secretaria Municipal de Saúde. Memorial Técnico - Processo de Reterritorialização. Fortaleza: Secretaria Municipal de Saúde; 2011.

12. Bulgarelli AF. Construindo sentidos sobre saúde bucal com idosos cadastrados em um Núcleo de Saúde da Família na cidade de Ribeirão Preto/SP. [tese]. Ribeirão Preto: Escola de Enfermagem de Ribeirão Preto, Universidade de São Paulo; 2010.

13. Bulgarelli AF. Saúde bucal em idosos: queixas relatadas, Ribeirão Preto/SP [dissertação]. Ribeirão Preto: Universidade de São Paulo, Faculdade de Medicina de Ribeirão Preto; 2006.

14. Haikal DS, Paula AMB, Martins AMEBL, Moreira NA, Ferreira EF. Autopercepção da saúde bucal e impacto na qualidade de vida do idoso: uma abordagem quanti-qualitativa. Ciênc Saúde Coletiva. 2011; 16(7):3317-29.

15. Lewandowski A, Bós AJG. Estado de saúde bucal e necessidade de prótese dentária em idosos longevos. Rev Assoc Paul Cir Dent. 2014;68(2):155-8.

16. SÁ IPC, Almeida Júnior LR, Corvino MPF, Sá SPC. Condições de saúde bucal de idosos da instituição de longa permanência Lar Samaritano no município de São Gonçalo-RJ. Ciênc Saúde Coletiva. 2012;17(5):1259-65.

17. Xavier AFC, Santos JA, Alencar CRB, Andrade FJP, Clementino MA, Menezes TN, et al. Uso dos serviços odontológicos entre idosos residentes no município de Campina Grande, Paraíba. Pesqui Bras Odontopediatria Clín Integr. 2013;13(4):371-6.

18. Martins AMEBL, Barreto SM, Pordeus IA. Autoavaliação de saúde bucal em idosos: análise com base em modelo multidimensional. Cad Saúde Pública. 2009;25(2):421-35.

19. Bulgarelli AF, Mestriner SF, Pinto IC. Percepções de um grupo de idosos frente ao fato de não consultarem regularmente o cirurgião dentista. Rev Bras Geriatr Gerontol. 2012;15(1):97-107.

20. Lima AMC, Ulinski KGB, Poli-Frederico RC, Benetti AR, Fracasso MLC, Maciel SM. Relação entre cárie dentária, edentulismo e autopercepção de saúde bucal em adolescentes, adultos e idosos de um município do nordeste brasileiro. Unopar Cient Ciênc Biol Saúde. 2013;15(2):127-33.

21. Gabardo MCL, Moysés SJ, Moysés ST, Olandoski M, Olinto MTA, Pattussi MP. Multilevel analysis of self-perception in oral health and associated factors in Southern Brazilian adults: a cross-sectional study. Cad Saúde Pública. 2015;31(1):49-59. 
22. Saintrain MVL, Souza EHA. Impact of tooth loss on the quality of life. Gerodontology. 2012;29(2):632-6.

23. Agostinho ACMG, Silveira JLGC, Campos ML. Edentulismo, uso de prótese e autopercepção de saúde bucal entre idosos. Rev Odontol UNESP. 2015;44(2):74-9.

Received: April 15, 2016

Revised: October 18, 2016

Accepted: February 06, 2017
24. Mestriner SF, Almeida ASQ, Mesquita LP, Bulgarelli AF, Mestriner Junior W. Oral health conditions and quality of life of elderly users of the Unified National Health System. Rev Gaúch Odontol. 2014; 62(4):389-94.

25. Rigo L, Basso K, Pauli J, Cericato GO, Paranhos LR, Garbin RR. Satisfação com a vida, experiência odontológica e autopercepção da saúde bucal entre idosos. Ciênc Saúde Coletiva. 2015;20(12):3681-8. 